\title{
Karel Šindelář
}

In memory of Academician Bohumil Bydžovský

Czechoslovak Mathematical Journal, Vol. 20 (1970), No. 1, 169-(170a),171-178

Persistent URL: http://dml.cz/dmlcz/100956

\section{Terms of use:}

(C) Institute of Mathematics AS CR, 1970

Institute of Mathematics of the Czech Academy of Sciences provides access to digitized documents strictly for personal use. Each copy of any part of this document must contain these Terms of use.

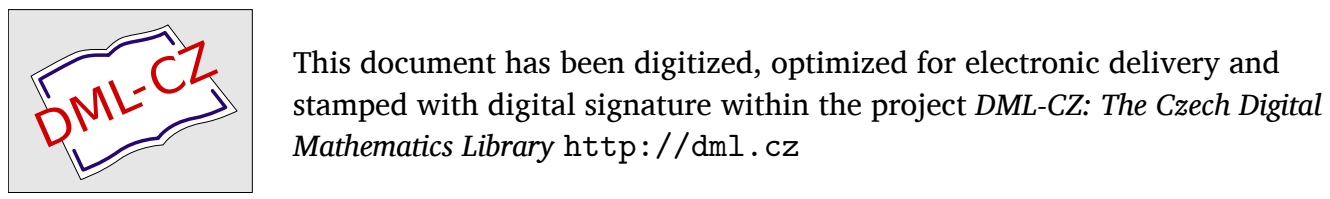


NEWS AND NOTICES

\title{
IN MEMORY OF ACADEMICIAN BOHUMIL BYDŽOVSKÝ
}

\author{
KAREL ŠINDELÁř, Žilina*)
}

Academician BoHUmil ByDžovský, Doctor of Sciences, Professor of the mathematic-physical faculty of Prague University, died at Jindřichův Hradec in South Bohemia on May $6^{\text {th }} 1969$. The news of his death saddened the Czechoslovak nation and in particular people working in the field of mathematics. For Academician Bydžovský was known not only as a great Czechoslovak scientist and mathematician but as a fine teacher who fascinated all who heard him, or had a chance to appreciate his stalwart character.

Bohumil Bydžovský was born on March $14^{\text {th }} 1880$ in Duchcov (North-West Bohemia) where his father JAN BYDŽovsKÝ worked as an engineer on the construction of the mines and railways. He was less than four years old, when his mother ANASTASIA, who was only twenty-four, died in the year 1883 . His father brought up the family of three boys and one girl. It is interesting to note that, though he never experienced genuine motherly love, the young Bohumil grew up to be a man, able to benefit others with his mental equilibrium and rare optimism.

In his early schooldays he had to attend a German school as often as there was no Czech school in the locality where his father worked.

From 1890 to 1898 he attended a well-known Czech grammar school in Prague (Akademické gymnasium) where he was an outstanding student not only in mathematics. At the same time he acquired a good grounding in English, French and Italian.

In the four years that followed from 1898 to 1902 he studied mathematics and physics at the philosophical faculty of the Charles University in Prague. Strangely enough in the beginning he did not concentrate on the exact sciences, but in his first years at university he devoted himself to philosophy and literature. Towards the end of his studies, he concentrated more on mathematics. Perhaps the man, who exerted the greatest influence on him, was Professor EDUARD WEYR, who awoke his interest in geometry.

Professor StudničKa and Professor Strouhal were the examiners at his finals in

*) I should like to express my sincere thanks to the family and the scholars of Academician Bydžovský for their help and interest while writing this article. 
the year 1902, and the following year 1903, he was proclaimed Doctor of Philosophy on the strength of his dissertation On hyperelliptic integrals, this time his opponents were Professors Petr, Koláček, Strouhal, Drtina and Masaryk.

These results were achieved while he was teaching at grammar schools in Prague, Kutná Hora and Kladno in Central Bohemia.

It was at this time, in 1904 to be exact, he married PhDr. MARIE KomínKoví, who also taught at the Prague grammar school for girls (Minerva). They had two sons. The elder Jan (born 1906) later worked as a mathematician-actuary at the International Labour Office in Geneva, where he represented Czechoslovakia, and later on, during the World War II, he worked at the Ministry of Foreign Affairs for the Czechoslovak government in London. Their younger son Ladislav (born 1908) is a wellknown lawyer, now the Secretary of the Constitution-law Committee of the Czechoslovak National Assembly.

Professor Bohumil Bydžovský gave up teaching at secondary schools in 1909 after his habilitation (venia docendi) at the Charles University in Prague. Later on his venia docendi was extended to cover the Czech College of Technology in Prague.

He was Associate Professor (Docent) until the year 1917 when he was named Professor of the Charles University. After the end of the World War I in 1918, he left the University and joined the newly established Ministry of Education of the Czechoslovak Republic as State Secretary, but after one year, he returned to the University and was named Full Professor in the year 1920.

In the year 1930 he was elected dean of the new independent faculty of sciences.

During the German occupation of Czechoslovakia 1939-1945 all Czech universities and colleges were closed on November $17^{\text {th }} 1939$. So Professor Bydžovský left Prague for his wife's birth-place Veselí nad Lužnicí (Veselí on the river Lužnice) in South Bohemia. But he was not safe there. The Nazis found out that his son Jan was living abroad with his family, so they arrested Professor Bydžovský and his wife and sent them to the concentration camp in Svatobořice near Kyjov in the South of Moravia. Fortunately they had no proof of their son's activity abroad, so they released them in the year 1943.

As soon as he reached home in Veselí, Professor Bydžovský started work in the resistance movement. He was elected honorary citizen of the town Veselí nad Lužnicí in 1947 after two years of brave and heroic action.

After the liberation of Czechoslovakia in the year 1945 Professor Bydžovský returned to Prague to lecture at the University again. He was elected rector of the Charles University in 1946 for one year. And the following study-year as prorector of the University, he became rector again, when new elections were held in the spring 1948 just before the $600^{\text {th }}$ anniversary of the Charles University. As rector of the University Professor Bydžovský directed the whole course of the celebrations extremely successfully. Academician Bydžovský went on working as Professor of the Charles University until as late as the year 1957 ; by then he had reached the ripe old age of seventy-seven years. 


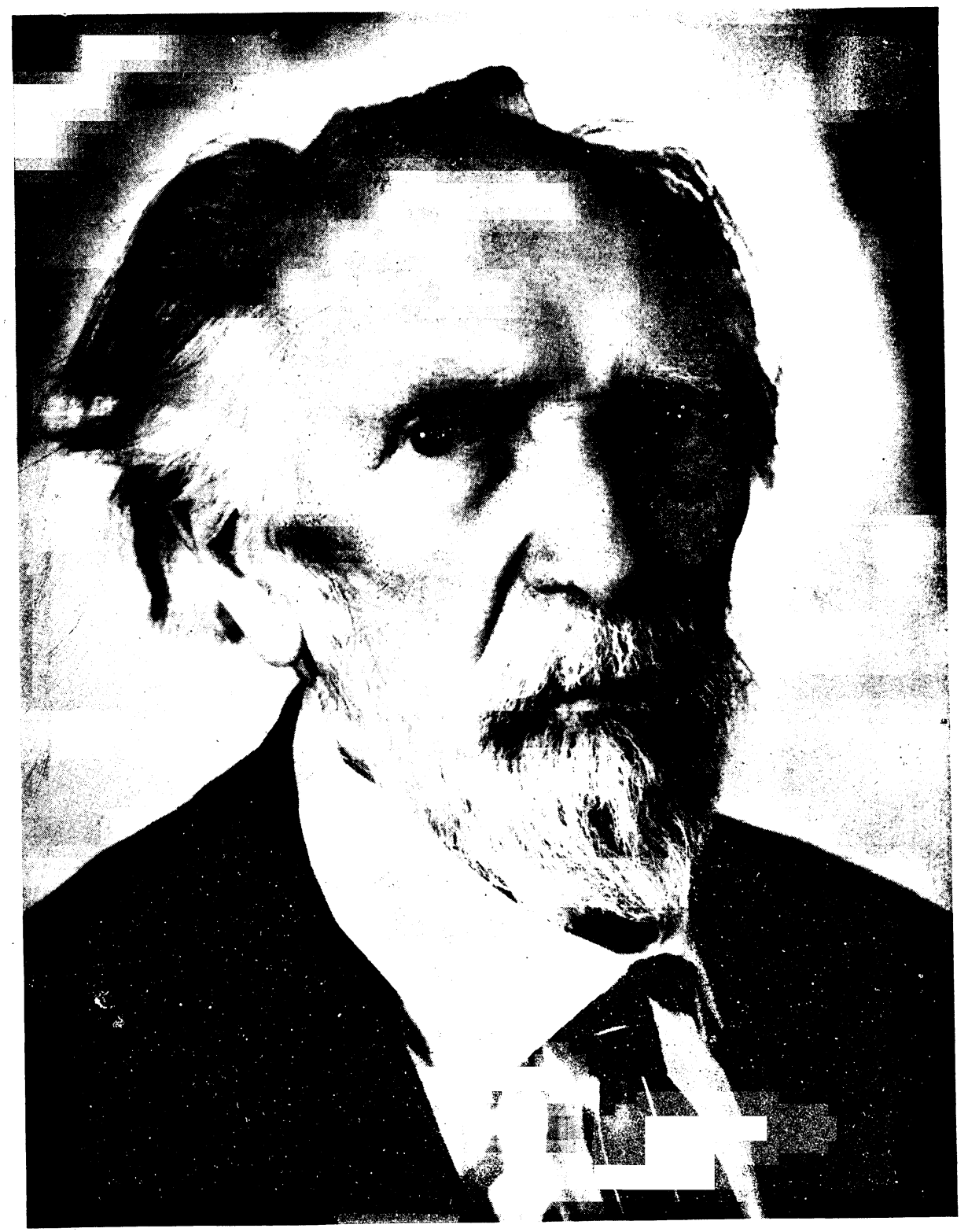

Academician BoHUmIL BYDžovskÝ 
Throughout his life Academician Bydžovský was concerned with didactics and he drew up enlightened reforms for Czechoslovak education and especially for secondary schools. He started this activity first in the Union of the Czech Mathematicians and Physicists of which he had been a member since 1898 and later in the First Republic with the blessing of the Czechoslovak Ministry of Education.

In the year 1909 he formed a committee of experts and scholars to write new textbooks for the Czech secondary schools. He himself wrote textbooks of arithmetics and book of examples and exercices for the higher classes and Professor Vojtěch joined him in the preparation of a Textbook of Mathematics for the highest class of Czech grammar schools.

The year 1917 found him leading a committee for grammar school reforms. And during the First Republic in 1923 he was appointed chairman of the committee for new concepts at the Czechoslovak Ministry of Education. This committee drew up two bills for school-reform, the second of which under IVAN DÉRER, the Minister of Education, was put into force in the year 1929 and was known as Dérer's schoolreform. This reform had a lasting effect on all Czechoslovak schools, especially grammar schools.

Professor Bydžovský sets out his ideas in his book [46] entitled Our grammar school reform which was issued (in Czech) in Prague as late as 1937 just on the eve of the World War II.

After the war he continued working for these reforms aiming at the introduction of a uniform secondary school, which actually was put into force after the year 1948 .

Never happier than when working Academician Bydžovský spent the last years of his life as chairman of the Committee for Mathematics of the Pedagogical Researchinstitute Jan Ámos Komenský in Prague.

Apart from textbooks for grammar schools, Professor Bydžovský wrote three textbooks for university students, namely Analytic Geometry (in Czech) published in the year 1923, the second Determinants and Matrices (in Czech) in 1930. Both books have been revised and published again since the war.

Professor Bydžovský's most outstanding book is no doubt the voluminous book Introduction to Algebraic Geometry (in Czech), which was published in the year 1948 in Prague. Long years of experience at the University are reflected in this work. Every detail shows the quality of a great scientist and it would be difficult to find a book to compete with it anywhere in the world. On the basis of this work, Academician Bydžovský was awarded the State prize for Mathematics in the year 1948.

As an active member of the Union of Czechoslovak Mathematicians and Physicists (Jednota československých matematiků a fysiků, JČMF) Professor Bydžovský had been a permanent member of the central committee since 1908 and in the years 1922 to 1935 he was chief-editor of the Czechoslovak Journal for the Advancement of Mathematics and Physics published by the Union with the support of the Czechoslovak Ministry of Education. In the years 1931-1933 as well as 1945-1956 he 
headed the Union as its president. And in the year 1928 he was the first honorary member ever elected to the Union.

From the year 1920 he worked side by side with Professors Petr and Hostinský as a member of the National Committee representing Czechoslovakia in the International Mathematical Union, the task being international cooperation in mathematics at research level.

In the year 1919 he became member-correspondent and in 1924 he was elected regular member of the Czech Academy of Sciences and Arts. This was followed in 1929 by his being elected a regular member of the Czech Royal Society of Sciences. Later as president he organized all its activities till 1952 when the Czech Royal Society of Sciences was closed. In the year 1949 he was elected chairman of the Czechoslovak National Research Council.

Czechoslovak scientific institutions underwent complete reorganization during the year 1952 and Professor Bydžovský was one of the first men to be appointed regular member of the newly established Czechoslovak Academy of Sciences thus becoming Academician. Although nearly seventy-three years old, he carried on doing important work, especially in the editorial field. Throughout his life Academician Bydžovský concerned himself with the organization of the Czechoslovak scientific and cultural life.

Academician Bydžovský was a scientist of integrity from his early years at the University in Prague till the end of his life. The last of his scientific works was published in the year 1963 when he was eighty-three.

Bydžovský's first works written when still a young research-worker [1], [2], [4] discuss rational curves in general and especially those of the $3^{\text {rd }}$ degree. From these works other similar works stemmed [3], [5], [6], namely the theory of plane and space collineations and their groups leading him to the study of plane cyclic collineations in [10]. The author returned to these themes frequently, e.g. in his works [14] and [15]. But at the same time he developed his own conception for the applications of elliptic functions in geometric research-work. And his masterly application of the theory of elliptic functions in algebraic geometry brought Academician Bydžovský world acclaim in the first half of his life.

In some of his later works, in addition to his own original and outstanding results, he deduced, applying his own method, many results actually discovered by the most distinguished world mathematicians. Some of their results were expressed with more precision or even had been corrected, other results were generalized or extended. Yet another no less important result brought out in his works [7] and [8] was a unifying survey of many analogical, but previously scattered pieces of knowledge on the theory of plane and space curves, which was reached by applying systems of points on a curve and their sets.

This was followed by a widening of his collineations-research leading him to the algebraic correspondences of higher degree - to Cremona transformations and their groups. He started from algebraic curves and concentrated on the study of Cremona 
transformations reproducing a plane or a space curve. In this works [9], [17], [23] and [24] he gave himself up to the study of quadratic transformations which bring about a certain birational correspondence between the points of a given curve. $\mathrm{He}$ dedicated himself for the most part to the study of plane curves of the $4^{\text {th }}$ degree, where there are less above-mentioned transformations than in the general case, in his works [25] and [29]. And in his work [29] he called them projectively specialized curves.

The works [26] and [27] of this group discuss projections of spaces with a given Cremona transformation into other (less dimensional) spaces, where the original transformation induces an analogic one. Using Cremona transformations, the author verified once again the most important result of his work [29] on projectively specialized quartics. And he dealt with these results again in his work [38] published several years later.

But Professor Bydžovský was able to make use of the apparatus of elliptic functions even in the case of nonelliptic curves. For example, he investigated plane curves of the $6^{\text {th }}$ degree containing eight or more double points whose genus is higher than 1 . And he deduced significant results applying elliptic functions to their adjoint curves as far as they are elliptic. In his work [12], he investigated in this way the position of the $9^{\text {th }}$ and the $10^{\text {th }}$ double point of a sextic whose eight double points are given. In another work [13], dealing with the same theme, the author deduces significant constructions of plane curves of the $6^{\text {th }}$ degree. He concerned himself again with plane sextics in his work [31], where he investigated nets of plane sextics. An interesting relation between elliptic sextics and sextics of genus higher than 1, which he discovered in his work, attracted the interest of Professor LUCIEN GodEAux in Belgium, who verified it again using his own method. Professor Godeaux's work was published in a Czech translation by Professor Bydžovský in the Czechoslovak journal in the year 1929.

The plane algebraic curves are treated yet again in some other works by Academician Bydžovský, especially [19], [20], [47], and [53]. In his work [19] he investigates the tangents of curves in their singular points making use of Cremona transformations. In his last work [53] he studies plane quartics with 12,8 or 4 points of inflexion and investigates cases, when those points form a full intersection of the curve with another one of a lower degree, i.e. cubic, conic section or a straight line. The last result was completed later by Professor Josef MetelKa.

This scientific research of Academician Bydžovský devoted to plane curves is connected with the so-called problem of projectivity for a bundle of plane curves, which the author discusses in his work [14] and especially [21], for a bundle of cubic curves.

These topics continue in Academician Bydžovskýs work [16] concerning the constructions in the theory of algebraic plane curves and in a certain sense even in his work [22], the main result of which is deduced by means of synthetic geometry.

In his works on algebraic plane curves, Academician Bydžovský not only introduced many a significant result of his own, but he also worked out a quite new original slant 
on many results known to mathematicians of preceding generations, especially Cremona, Cayley, Salmon, Halphen, Bertini and others.

Space curves are investigated in Academician Bydžovskýn's works [11] and [18], his only works outside algebraic geometry and concerned with differential geometry. He investigates in them the problem of trochoids creating projections of geodesics on central quadratic surfaces and further conic surfaces creating themselves, by a special rolling along a given surface, curves, which are its own geodesics.

Quadratic surfaces are treated in his work [49] written with co-author Professor Vladimír KNICHAL.

The second and no less important part of Academician Bydžovský's scientific research concerns birational correspondences developed from his first works [3], [5], [6] and [10] mentioned above. From linear correspondences the author moves towards Cremona transformations which he applies in a masterly way in the study of algebraic curves. Thus almost all his works concerned with curves are also connected with birational correspondences. And on the contrary the study of birational correspondences and their groups is frequently based on algebraic curves, especially concerning proofs of completeness in the works [34] and [35]. These topics are further developed in the works [32], [33] and [36].

The most general results are contained in the work [39] discussing involutory quadratic transformations in $n$-dimensional projective spaces. Quadratic involution is decomposed into an inversion and a homology and conditions are found under which composing two inversions produces a quadratic involution.

The third thematic part of Academician Bydžovský's research are his works on configurations. He got interested in these topics late in his life, however he achieved remarkable results. The first work about configurations [30] was published as late as in the year 1927. It discusses Brianchon's configuration in connection with Pascal's and Hesse's configurations, where elliptic functions are used again. The next work in this group [48] was published twelve years later. It contains a new type of plane configurations $\left(12_{4} ; 16_{3}\right)$. This work was accepted with enthusiasm by Professor MAX ZACHARIAS in Berlin, who later took up the topic himself. After the break during the World War II and occupation, Academician Bydžovský came back to plane configurations in his works [50] and [52].

The scientific works of Academician Bydžovský were published for the most part in Czech with summaries in a world-language (usually in French). And his name stood out before the international mathematical public only at international mathematical congresses.

The first congress was in Strasbourg in the year 1920, where he read a paper on quadroquadratic transformations which reproduce a certain plane elliptic quartic without any change. This paper was published as one of his works [23].

When he was forty-four, he was elected vice-chairman of the International Mathematical Congress in Toronto in 1924, where he presented a paper on sextics with eight double points. This paper later appeared as his work [28]. 
He also took part in the next Congress in Bologna 1928 with his paper about groups of Cremona transformations, also published as one of his works [32].

One year later he presented another paper at the Congress of Mathematicians of Slavonic countries in Warsaw 1929 about a special kind of Cremona plane transformations likewise published later as his work [33].

He also took part in the next Congress of Mathematicians of Slavonic countries in Prague 1934, where he read his paper on quadratic involutions in $n$-dimensional space, now known as his work [42].

And two years later he took part in the last World Congress before the war in Oslo 1936, where he read his paper on decomposition of quadratic involution in $n$ dimensional spaces, later published as his work [45].

After the World War II he was elected Czechoslovak chairman of the Congress of Czechoslovak and Polish Mathematicians in Prague 1949, where he presented his paper on configurations $\left(12_{4} ; 16_{3}\right)$. This paper was published as his work [50].

Besides international congresses on mathematics, Professor Bydžovský represented Czechoslovak science, in particular mathematics, on many other occasions, for instance after the World War II in the year 1946 in London and Nice, 1947 in Princeton, 1948 in Warsaw and elsewhere.

His scientific research is so extensive that it is quite impossible to enumerate all his ideas in such a brief treatise.

Apart from all that, Academician Bydžovský was very active reviewing foreign textbooks on algebraic and differential geometry for the Czechoslovak Journal for the Advancement of Mathematics as well as informing mathematicians in the rest of the world about mathematical events in Czechoslovakia, mostly in Revue semestrielle des publications mathématiques and in Jahrbuch über die Fortschritte der Mathematik and in other international reviews.

Academician Bydžovský cooperated with teams of editors on encyclopaedias elaborating mathematical items for the general Czechoslovak public. In fact, Academician Bydžovský's name appears frequently in both popular and scientific Czechoslovak and world publications about mathematics. For instance his work [42], which Academician Bydžovský considered to be only a methodical one, is quoted in an Encyclopaedia by the Italian mathematician BERzoLARI and described as a work of pioneering character.

Many of Academician Bydžovský's students are known throughout the world; among them are Professors BíleK, HavlíčeK, J. Metelka and V. Metelka and the now deceased mathematicians MACHYTKA, RösSLER and SRB. In Slovakia his best known followers are Professors Palaj and SviteK.

Academician Bydžovský was never jealous as scientist. He always took pleasure in the scientific success of his colleagues and particularly of his students. In the last years of his life, he liked to help all his previous students with guidance and advice.

The life-work of Academician Bydžovský was highly appreciated in Czechoslovakia as well as abroad. In Czechoslovakia he was honoured with membership or chairman- 
ship of the highest Czechoslovak scientific and cultural bodies. Besides that he was a member of French, Yugoslav, Polish and other scientific institutions abroad.

In the year 1948 he was awarded doctorate honoris causa of the University in Warsaw, in 1965 of the Charles University in Prague and in 1968 of the Palacký University in Olomouc.

Those were followed by further high distinctions. In the year 1955 he was awarded the Order of the Republic, in the year 1962 the Jan Ámos Komenský-medal. He was also holder of the Czechoslovak State-prize for Mathematics and of many other distinctions.

But acclaim and success never altered Academician Bydžovskýs modest way of life. He simply accepted any honour as a new task to be accomplished. And he was never daunted by any work right up to his old age, and indeed he possessed an enormous talent for organization apart from his scientific and pedagogical genius. He regarded work solely as service for those around him, for his own country and for the whole of mankind.

Academician Bydžovský was a wonderful teacher. His lectures were detailed with minute care and given with such brilliance that any student lucky enough to hear him was able to penetrate previously insurmountable problems.

Requiring his students to solve at least one problem every day, they had to admit, that their master himself followed the same principle. When examining, none was happier than he, if the student succeeded. He was never impatient nor ironical. His personality calmed those students who were upset and nervous. And thus he was even as examiner much sought after, although he was very exacting. He was never moody at all, neither did he allow his own personal worries to afflict the students.

Academician Bydžovský was a very good husband, a unique father, grandfather and great-grandfather. The atmosphere at home always radiated harmony and happiness.

However sometimes he and his family fell victim to his principle, Truth and only truth at any price. So during the World War II and the German occupation of Czechoslovakia, he and his wife were imprisoned in a concentration camp, and after the war, in the period of deformations, his son Jan Bydžovský was arrested and many years imprisoned, though completely innocent. When his son was released from prison and then in 1965 rehabilitated, his father seemed to become years younger, but only for a short time.

Even in the worst moments of his life, Academician Bydžovský never despaired and never lost his faith in justice. He never abandoned his progressive principles, for which he fought all his life. Until his death he knew how to find time for his many personal interests and how to draw happiness from them. He faced all trials and sorrows with a rare sense of humour, which he never lost until his ripe old age.

Academician Bydžovský departed from this life May $6^{\text {th }} 1969$ to be followed three weeks later by his wife PhDr. Marie Bydžovská, born Komínková.

A great man had died, a noble-hearted man of genius and simplicity, leaving behind his family, his scholars and all those who loved him and who will never forget him. 


\section{BIBLIOGRAPHY}

Annotation: 1. Czechoslovak Journal for the Advancement of Mathematics and Physics (written mostly in Czech with summaries in world-languages) - Casopis pro pěstování matematiky a fysiky (since 1950 Časopis pro pěstování matematiky) briefly denoted as "Časopis". 2. Dissertations of the $\mathrm{II}^{\text {nd }}$ class of the Czech Academy of Sciences and Arts (written mostly in Czech with summaries in world-languages) - Rozpravy II. třídy České akademie věd a umění briefly denoted as "Rozpravy". - 3. Bulletin of the Czech Royal Society of Sciences (written mostly in Czech with summaries in world-languages) - Věstník Královské české společnosti nauk below denoted as "Věstník". - 4. Czechoslovak Mathematical Journal (written in worldlanguages) below denoted as "Journal".

[1] Droite d'inflexions d'une cubique rationnelle. Časopis $X X X V, 1905$.

[2] Contribution à la théorie d'un faisceau de cubiques rationnelles. Programme of the Kladno grammar school (reálka) 1905/6.

[3] Détails concernant la théorie de la collinéation cyclique ternaire. Programme of the Kladno grammar school (reálka) 1906/7.

[4] La courbe cubique rationnelle générée par l'ensemble des paires de points conjugués. Časopis $X X X V I I, 1907$.

[5] Sur un groupe de collinéations planes. Časopis $X X X V I I I, 1908$.

[6] Un groupe de six collinéations dans le plan ou dans l'espace. Programme of the Karlín grammar school (reálka) 1907/8.

[7] Groupe de collinéations d'une courbe gauche biquadratique de première espèce, I. Rozpravy $1908,18$.

[8] Groupe de collinéations d'une courbe gauche biquadratique de première espèce, II. Rozpravy 1908, 27.

[9] Sur un groupe infini de transformations de Cremona. Rozpravy 1909, 34.

[10] Contribution à la théorie des projectivités cycliques. Časopis $X L, 1911$.

[11] Sur la génération des lignes géodésiques sur les ellipsoïdes de révolution. Časopis $X L I, 1912$.

[12] Points doubles des courbes de sixième ordre. Rozpravy 1912, 42.

[13] Construction des sextiques planes de genres 0 à 3. Rozpravy 1913, 46.

[14] Solution d'un problème spécial de projectivité et son application. Časopis XLIII, 1914.

[15] Remarque sur les points d'inflexion d'une cubique à point double (in French). L'Enseignement mathématique, Genève, 1914-16.

[16] Sur une espèce spéciale des constructions. Věstník 1914.

[17] Sur un théorème concernant les courbes elliptiques normales (in French). Bulletin international de l'Académie des Sciences de Bohême, 1915.

[18] Sur la génération des lignes géodésiques sur les surfaces centrales du deuxième degré de révolution. Casopis $X L I V, 1915$.

[19] Courbes planes du $2 n^{\text {ième }}$ degré à trois points $n$-uples. Časopis $X L V, 1916$.

[20] Points réels hyperosculateurs des courbes algébraiques planés. Rozpravy 1916.

[21] Solution d'un problème de projectivité spécial pour un faisceau de cubiques. Rozpravy 1917, 20.

[22] Sur un exemple de transformation multivoque du plan. Časopis XLVII, 1918.

[23] Sur les transformations quadratiques reproduisant une quartique elliptique plane (in French). Comptes rendus du Congrès international des mathématiciens, Strasbourg, 1920. 
[24] Sur les transformations quadratiques d'une quartique plane générale de genre un. Rozpravy $1920,17$.

[25] Réduction du nombre de transformations quadratiques d'une quartique elliptique plane. Rozpravy 1920, 23.

[26] Application du principe de projection dans la théorie des correspondances géométriques. Casopis $L I, 1922 ;$;II, 1923.

[27] Sur les quartiques elliptiques planes, spéciales au point de vue projectif (in French). Rozpravy, 1924, 32.

[28] Contribution à la théorie de la sextique à huit points doubles (in French). Proceedings of the international Congress of Mathematicians, Toronto, 1924.

[29] Remarque à l'étude des quartiques planes spéciales, Časopis LIII, 1924.

[30] Contribution à la théorie de la configuration de Brianchon. Rozpravy 1927, 36.

[31] Contribution à la théorie des sextiques elliptiques. Casopis $L V I I, 1928$.

[32] Remarque sur les groupes finis de transformations de Cremona (in French). Atti del Congresso internazionale dei matematici, Bologna, 1928.

[33] Sur certains groupes de transformations de Cremona dans le plan. Proceedings of the Congress of Czechoslovak Natural historians and Physicians, Praha, 1928.

[34] Sur les involutions symétriques du cinquième ordre (in French). Rozpravy 1929, 2.

[35] Sur une espèce particulière de groupes d'involutions planes de Cremona (in French). Věstník 1929, XI.

[36] Sur une espèce spéciale de groupes d'involutions de Cremona dans le plan. Proceedings of the Congress of Mathematicians of Slavonic Countries, Warsaw, 1929.

[37] Soins linguistiques du travailleur scientifiques. Volume of Sciences VII, published by the Czech Academy of Sciences and Arts, Praha, 1930.

[38] Les homographies des courbes cubiques harmoniques et equienharmoniques. Časopis LIX, 1930.

[39] Sur les involutions quadratiques dans l'espace à $n$ dimensions. Časopis $L X, 1931$.

[40] Jan Sobotka. Obituary, published by the Czech Academy of Sciences and Arts, Praha, 1932.

[41] Bedřich Procházka. Obituary, published by the Czech Academy of Sciences and Arts, Praha, 1934.

[42] Sur les involutions quadratiques dans l'espace à $n$ dimensions (in French). Comptes rendus du II ième Congrès des mathématiciens des pays slaves. Prague, 1934.

[43] Sur les matrices orthogonales symétriques (in French). Casopis 65, 1936.

[44] Cas spécial de la transformation quadratique involutive dans l'espace à $n$ dimensions (in French). Věstník 1936.

[45] Décomposition d'une transformation quadratique involutive dans l'espace à $n$ dimensions (in French). Comptes rendus du Congrès international des mathématiciens, Oslo 1936.

[46] Réforme de notre école secondaire. Praha 1937.

[47] Sur les points et les coniques sextactiques d'une cubique plane (in French). Časopis 68, 1939.

[48] Über eine ebene Konfiguration $\left(12_{4} ; 16_{3}\right.$ ) (in German). Věstník 1939, 2.

[49] Sur l'invariant simultanné $\Phi$ de deux quadriques (in French, with Professor Knichal). Bulletin international de l'Académie des Sciences de Bohême, 1940.

[50] Quelques remarques concernant la théorie de la configuration $\left(12_{4} ; 16_{3}\right)$. Casopis $74,1949$.

[51] Sur certains points remarquables d'une cubique rationnelle plane (in French). Casopis $75,1950$.

[52] Über zwei neue Konfigurationen (in German). Journal 4 (79), 1954.

[53] Über die Inflexionspunkte einiger ebenen Kurven vierter Ordnung. Časopis 88, 1963. 